\title{
Assessment of biodiversity conservation in Entoto Natural Park, Ethiopia for ecotourism development
}

\author{
ASFAW DEMEKE TESEMA, GETACHEW BERHAN" \\ School of Earth Science, Addis Ababa University. Addis Ababa, Ethiopia. `email: getachew@aau.edu.et \\ Manuscript received: 4 November 2018. Revision accepted: 16 May 2019.
}

\begin{abstract}
Tesema AD, Berhan G. 2019. Assessment of biodiversity conservation in Entoto Natural Park, Ethiopia for ecotourism development. Asian J Ethnobiol 2: 22-37. The study's main goal was to use Geographic Information Systems (GISs) and remote sensing to generate biodiversity and land use/cover changes to develop ecotourism in Ethiopia's Entoto natural park. During field verification, the primary data was collected. Questionnaires and interviews were conducted to assess the status of biodiversity, prospects, and opinions for creating ecotourism in Entoto Park to collect the required primary data for this research. Different and suitable software was used to process remotely sensed data depending on the data type. Since the field verification provided a priori information, the imageries were classified using the supervised classification technique. The field verification results revealed that 25 different tree and shrub plant species were discovered in the Entoto natural park. The responses to questionnaires and details gathered from personal interviews were nearly identical to the data collected in the field. Almost $88 \%$ of the overall species abundance in the study region was accounted for by Eucalyptus globulous and Juniperus procera. In an ArcGIS and ERDAS Imagine the setting, outputs such as change detection maps and topography maps were developed. The analyses revealed that the region's forest cover has increased when comparing successive decadal results. The land in these park areas could be used for new campgrounds, various developed structures and amenities such as lodging and venues, and nature-based activities such as canopy walks. This study will contribute to the literature on the importance of biodiversity in the growth of ecotourism and the benefits of ecotourism to environmental conservation and their close coexistence. Entoto Natural Park can be considered a suitable site for ecotourism promotion based on the existing resources of the studied region and the assessment results.
\end{abstract}

Keywords: Afromontain, biodiversity, criteria, ecotourism, GISs, sustainable

\section{INTRODUCTION}

Forest habitats, for example, cover most of the Earth's surface. The earth sciences provide new information about the natural environment and its resources (Fedorov 1980). The rise and advancement of geospatial technology have made it possible to capture, store, process, analyze, and view spatial data for various environmental applications. The data collected by Remote Sensing is related to the Earth's electromagnetic properties. The data can be linked to real-world parameters or features in various ways. Remote sensing is the instrumentation, techniques, and process of observing the Earth's surface from afar, acquiring data, and interpreting the images or numerical values to gain accurate information about specific Earth objects.

Ethiopia has a wide range of geographical features and macro-and microclimatic variations. There are ten ecosystems in the region, 18 major and 49 minor agroecological zones. Ethiopia is home to over 6,000 species of higher plants, with $10 \%$ of them being endemic to the country. The Ethiopian Biological Diversity Institute/EBI reports that the country has 284 species of wild mammals and 861 species of birds (Ethiopian Biological Diversity Institute/EBI, 2014). The country has a rich diversity of plant and animal genetic capital. Ethiopia is one of the world's most biologically diverse nations. The country is implementing two area closures to reconstruct and restore damaged areas. The first is to isolate an area from livestock and people to regen natural vegetation. The second is to separate degraded lands while introducing additional steps such as seedling planting, mulching, and building water harvesting systems to improve and speed up the regeneration process (et.chm-cbd.net/biodiversity/biodiversity-ethiopia).

Entertainment and recreation are essential to humans, considering conservation and long-term utilization goals. As a result, establishing and constructing forest parks and resource conservation are necessary to draw visitors, generate revenue, and provide leisure and relaxation. The recognition that the Protected Landscape approach offers both a functional and economic position for farmers and an essential structure around which environmental protection can be connected to improving local people's quality of life is critical (Okello 2003). The perceived potential of ecotourism as an important tool for sustainable development is the primary reason that developing countries are now incorporating it into their economic development and conservation strategies. In the 1990s, ecotourism arose as an alternative type of tourism to address the shortcomings of traditional (mass) tourism in meeting the needs of sustainable growth. Ecotourism is often described as any type of tourism that involves nature. The above activities often include the placement of a hotel in a beautiful landscape, to the detriment of the environment. Above all, ecotourism must educate people about the beauty and fragility of nature. Bunruamkaewa and Murayama (2011) 
oppose the actions of some operators who disseminate their activities by using the terms "green" and "eco-friendly" while acting in environmentally insensitive ways. Ecotourism has long been common in developing countries worldwide, and it is likely to continue to expand. The majority of ecotourism tourists are mature and wealthy. They are a decent source of revenue for tour companies, but they can also be challenging. They are usually interested in a variety of tours, including safari-style luxury tours to explore wildlife, birds, and landscapes, as well as more modest adventure tours that emphasize remote areas, colorful people, or unusual geologic features.

Ethiopia is rich in such assets that can provide a diverse range of experiences and opportunities to observe local life and natural attractions, such as those that already exist at Bishangari on Lake Langano and the site in the Afar region, and others that are in the planning stages (Henze 2007). As Ethiopian tourism expands, more of the country's attractions will become available to visitors, including international tourists, diaspora visitors, foreign residents, and Ethiopian people. Ecotourism is a good fit for students and young adults who are less wealthy and comfortable with simple housing and fewer amenities. Trekking, discovering remote landscapes, wild animals, birds, river and lake encounters, and studying exotic ethnic groups are all things they're interested in. Person and community tours funded by organizations are available for scholars with a professional interest in ethnography, archaeology, various aspects of biology, and geology (Malede and Girma 2015). Ecotourism is a low-impact, mostly small-scale alternative to traditional commercial (mass) tourism that involves visiting delicate, untouched, and relatively undisturbed natural areas. Ecotourism has always been a part of Ethiopian tourism. Visitors to the historical sites are mainly interested in Ethiopia's past and the extraordinary achievements of Ethiopians over millennia. But they're also curious about the physical characteristics of these areas and how well they're covered. Some travel companies specialize in animal and bird-watching tours and tours to see native forests and rare geologic features (http://www.eunwto.org/doi/book/ 10.18111/9789284416899).

After the World Ecotourism Summit held in 2002, the ecological tourism sector has been increasingly concerned since it is supposed to act as an instrument to ensure that destination areas are safe, support the tourist population, and contribute to poverty reduction. According to recent WTO market surveys, the growth of ecotourism demand would particularly benefit Africa (Theodros 2004). The area is more likely to draw visitors in the region (http://www.e-

unwto.org/doi/book/10.1811/9789284416899) both from ecotourism tours and those looking for newly-developed destinations which are abundant in the region. In Ethiopia, conservation and sustainable use activities are being actively undertaken. Consequently, significant changes have been made to the status of such biodiversity resources. For example, rehabilitation and restoration of degraded areas, forestation, and sustainable management practices of natural resources led to increased forest cover and improved associated biodiversity (EBI, 2014).
The current study aims: (i) to generate changes in biodiversity and land and coverage by using indices derived from geospatial data, (ii) to evaluate the status of the study area for biodiversity conservation. (iii) to calculate the land use and cover and produce maps, (iv) to identify multi-faceted ecotourism growth threats and opportunities.

\section{MATERIALS AND METHODS}

\section{Materials}

The study used a purposive sampling approach to collect data from various stakeholders. Ethiopian Heritage Trust, Addis Ababa Culture and Tourism Development Bureau, Ministry of Culture and Tourism, Institute of Biodiversity, Addis Ababa City Administration's Environmental Protection Bureau, and other relevant institutions were contacted for primary data collection. The second task was to collect data on biodiversity conservation and ecotourism production in the Entoto Natural Park from key stakeholders and other relevant sources.

During field verification, the primary data was collected. Moreover, during the transect walk, there were both difficulties and opportunities. Various datasets variety from multiple sources, such as satellite data, maps, and plant measure data, were processed to support this research. Literature, the Internet, electronic source materials, and other secondary data were also used in this analysis. Threedecade time-series datasets were analyzed to identify shifts in the land use/cover of the Entoto natural park. For remote sensing of vegetation resources, satellites such as ASTER, IKONOS, Landsat 5 TM (Thematic Mapper), Landsat 7 ETM+ (Enhanced Thematic Mapper), Quickbird 2, RapidEye, SPOT 5 (Satellite Pour l'Observation de la Terre), and Worldview-2 are frequently used.

One of the significant input datasets for this analysis was remotely sensed data. For the studies, imageries from the Landsat system acquired in 1986, 1995, and 2015 and a SPOT image from 2006 were used. The Ethiopian Mapping Agency provided maps at scales of 1:50,000 and $1: 250,000$. EMA provided the vector data (road, river, and contour) digitized from two 1:50,000 topographical paper maps. Other data types were used for terrain analysis, elevation data collection, and displaying the study area's general topographic characteristics. These data forms include TIN, DEM, and SRTM, which are used to display the slope and feature of an area and were downloaded from the internet (www.earthexplorer.com and www.glcf.com). Additional sources of information include legal, regulation, assessment studies, and media sources.

The Institute of Biodiversity and Conservation provided formats for collecting vegetation data, including floral richness, tree/shrub species, seedling and sapling data, and Land Cover Relieve Data Sheet. A Global Positioning System (GPS), a Compass, and a Map of 1: 50,000 scales were used for field verification. A GPS was used to record each sample map's positions (coordinates) (Table 2). The information needed for this study came from several places. Various references, studies, and blogs helped me 
learn about existing policies, programs, projects, best practices, and so on.

\section{Methodology}

The first step in the methodology was to conduct a thorough analysis of the current literature to gather both theoretical and secondary data. Both quantitative and qualitative approaches were used in this thesis. Questionnaires and interviews were used to collect primary data to assess the status of biodiversity. Questionnaires were used to collect opinions from interested experts to identify prospects for the advancement of ecotourism in Entoto Park. Qualitative data were collected using semistructured questionnaires, a transect walk, and field observations transcribed and analyzed. When the questionnaires were returned, a personal interview was conducted with a select group of respondents to delve deeper into their perspectives on conservation and ecotourism promotion. Key members from the Ethiopian Ministry of Tourism and EHT received questionnaires. Most of the interviews were conducted in person, with a few conducted over the internet. Respondents were asked about the park's viewpoint, the most significant environmental effects, and the factors they believed led to its existence. Digital recordings were made of the interviews, and notes were taken. One of the techniques used in this study's field data collection was systematic sampling. The systematically formed quadrats along each transect recorded all trees and shrubs. During field verification, the primary data was collected.

Moreover, during the transect walk, there were both difficulties and opportunities. The study used a purposive sampling approach to collect data from various stakeholders. Ethiopian Heritage Trust, Addis Ababa Culture and Tourism Development Bureau, Ministry of Culture and Tourism, Institute of Biodiversity, Environmental Protection Bureau of the Addis Ababa City Administration and other relevant institutions were contacted for primary data collection. The second task was to collect data on biodiversity conservation and ecotourism production in the Entoto Natural Park from key stakeholders and other relevant sources.

The data was then analyzed using geospatial, remote sensing, and GIS techniques. Integration of all datasets (raster, vector attribute, and statistical) is one of the most important procedures for assessing the spatial changes in land use/cover and biodiversity in the study areas. Remotely sensed data needs some pre-processing before being used directly, in which the atmospheric effect and geometric error are corrected, among other things. The spectral profile is a graphical representation of the reflectance spectrum of a single pixel. Improving the image was one of the techniques used. Any sensor system, as stated, has a variety of sources of noise, resulting in a few erratic pixels. Thus, satellite data were pre-processed and improved to eliminate noise and radiometric error, and they were made ready for further interpretation and study before being used. Enhancement techniques can be used in Multispectral Scanner (MSS) data to reduce atmospheric and sensor variability with minimal pre-and post- processing. The process of making an image more interpretable for a specific application is known as image enhancement. The resolution merge function has been implemented to resample data with a low spatial resolution $(30 \mathrm{~m})$ to a higher spatial resolution $(15 \mathrm{~m})$ while retaining spectral information. A sensor's resolution can be described in radiometric, spatial, spectral, or temporal resolution. Enhancement improves the human eye's ability to perceive essential features of raw, remotely sensed data. Enhancement techniques are also used to analyze and locate areas and items on the ground and extract the best information from the raster data instead of classification techniques (Faust 1989). Data integration was one of the methods used to make the data consistent.

Ethiopia is home to over 6000 species of higher plants, with $10 \%$ of them being endemic to the country. There are 284 species of wild mammals and 861 species of birds in the world. There are little data on other wild animals, with only 201 reptiles, 200 fish, 63 amphibians, and 1,225 arthropod species reported. Ethiopia is home to 29 wild mammals, 18 bird species, ten reptiles, 40 birds, 25 amphibians, and seven arthropod species. Ecosystems and various wild plants and animals, including endangered species, farmer varieties, and indigenous animal breeds, are all decreasing due to direct and indirect pressures. As a result, 103 tree and shrub species, 31 bird species, one reptile, nine amphibian species, two fish species, and 14 other invertebrate species are threatened (EBI 2014).

\section{The study area \\ Study area description}

The Entoto Natural Park was created with the love of a few people. It's between $38^{\circ} 48^{\prime} 00^{\prime \prime}$ and $38^{\circ} 47^{\prime} 01^{\prime \prime}$ East, and $09^{\circ} 04^{\prime} 05^{\prime \prime}$ and $09^{\circ} 07^{\prime} 33^{\prime \prime}$ North. The park is 2,300 hectares in size and is located on the south-eastern slopes of Mt. Entoto between the northern limit of Addis Ababa (at 2,600 m) and the track along the mountain ridge (at over 3,100 m) (figure 2). The Entoto escarpment, including the Entoto natural park, has 1,300 ha Ethiopian Heritage Trust (EHT). Several researchers have looked into the geology of Addis Ababa and its environs. At the crest of the Entoto hills and across the Sululta plains, the Alaji basalts can be seen. They are the oldest rocks in the Alaji cycle, forming high topography (ridges). The texture of these basalts ranges from porphyritic to aphanitic. The Entoto mountain chains in the north are rhyolite and trachyte with a small amount of obsidian-rich tuffs known as the Entoto silicic. They are part of the Alaji formation and sit atop older basalt. Rhyolites are porphyritic, with quartz, sandstone, andesineoligoclase phenocrysts and a devitrified glass, iron oxide, plagioclase, and quartz groundmass. The trachytes are composed of phenocrysts of anorthoclase sanidine, oligoclase, magnetite, and a groundmass of plagioclase (Haileselassie and Getaneh 1989).

The study area has a diverse range of vertic cambisol soil types. The Entoto Hill Chain, on which the Entoto Natural Park is located in the northern part of Addis Ababa, is made up of basalts that are covered in one to two meters thick volcanic topsoil materials. Entoto's predominant soil type is clay, and topsoil materials in the western areas are 
thick and soft in comparison to those in the northern and eastern parts. The mountain is made up of a tilted block of bedrock with very steep, soil-free slopes and cliffs on the northern side and much longer, shallower slopes on the south-eastern side. Sharp changes in the inclination of the slope, as well as some flat land areas, are common in different parts of the region. The tops of the hills and ridges, which include Entoto streams, are densely forested.
The park is a great place to see vultures (i.e. five species), as well as eagles, buzzards, hawks, larks, and ravens. Gypaetus barbatus (a significant population exists in the Entoto and Gorfu hills), Buteo oreophilus, Bubo capensis (historical records only), Aquila wahlbergi, and Accipiter rufiventris are all of particular interest. The park is home to a variety of Palearctic and intra-African migrant animals (EWNHS, 2015).

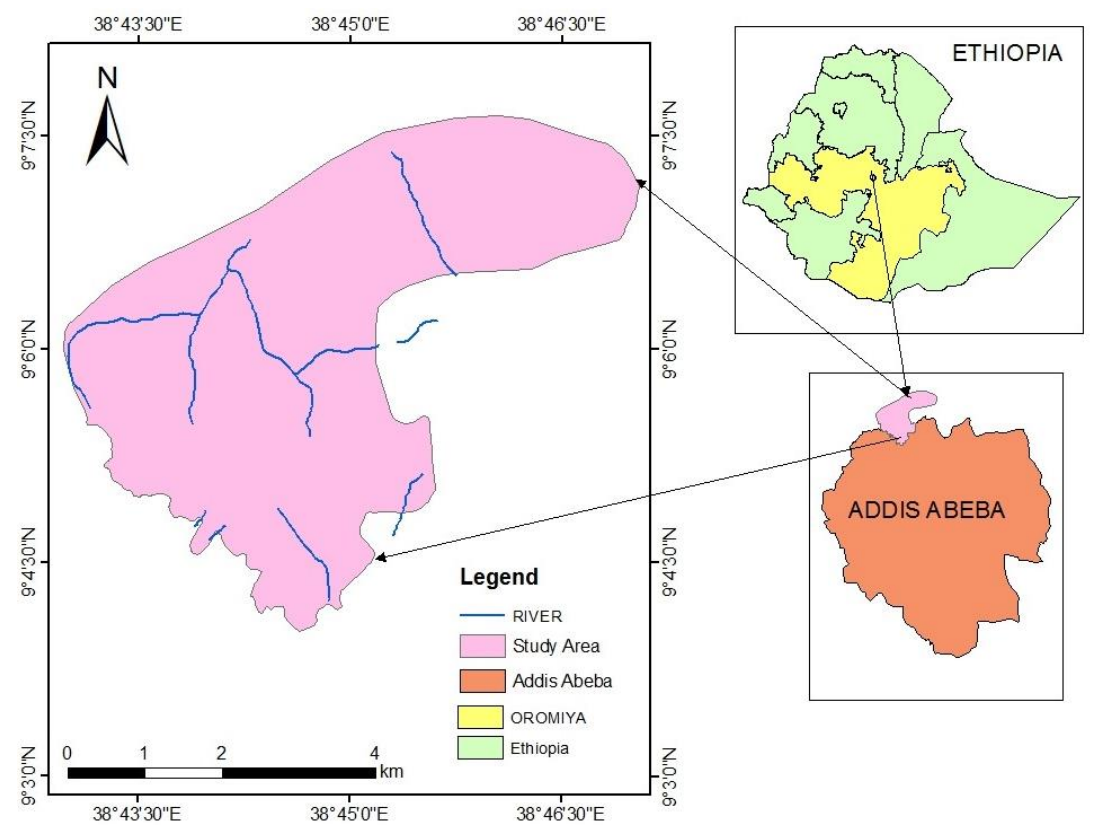

Figure 2. Location map of the study area

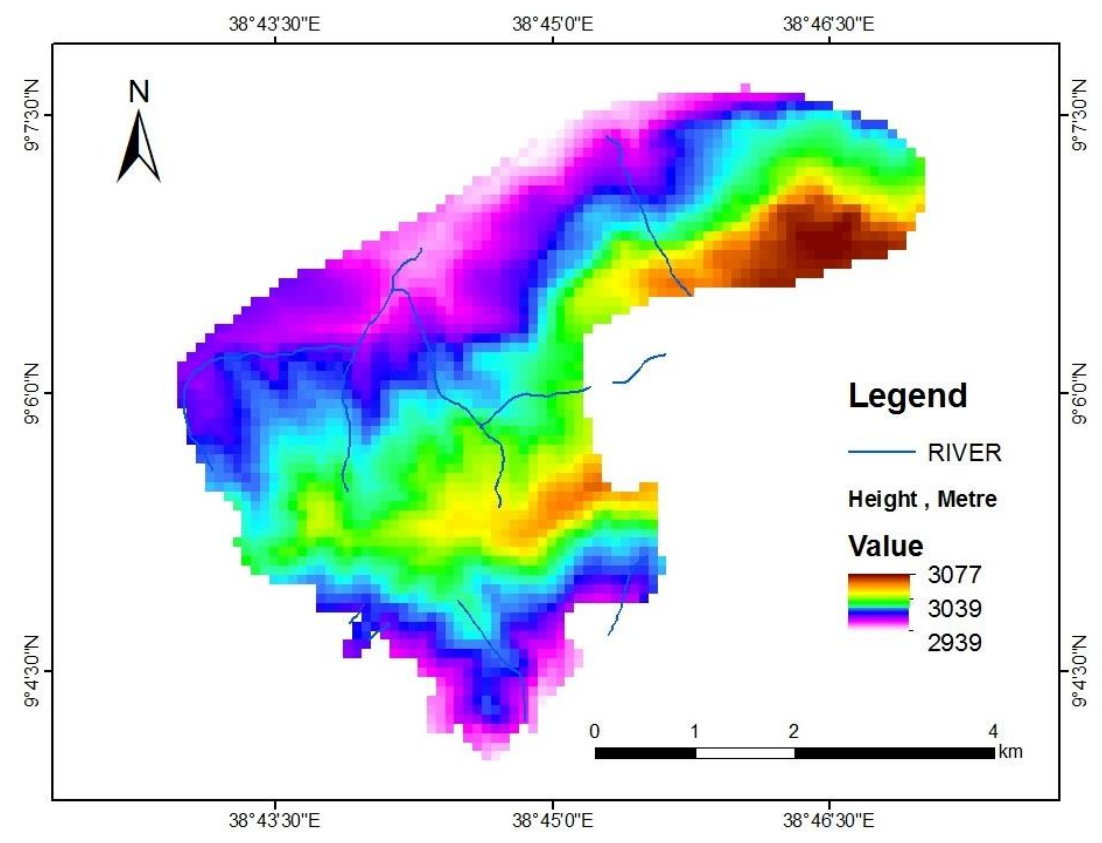

Figure 3. Topographical map of the study area 


\section{Topography}

The Entoto Natural Park is located on the south-eastern slopes of Mt.Entoto, between $(2300 \mathrm{~m}-3,100 \mathrm{~m})$ the northern limit of Addis Ababa (at 2,600 m), and the track along the mountain ridge is (at over 3,100 $\mathrm{m}$ ) the highest point in Ethiopia (Figure 3). Low pressure, also known as the Inter-Tropical Convergence Zone, moves across the equator seasonally northward and southward on the African continent, affecting the climate in Entoto Natural Park. The average maximum temperature is $24.3^{\circ} \mathrm{C}$ in May and $20.3^{\circ} \mathrm{C}$ in August, while the average minimum temperature is $11.8^{\circ} \mathrm{C}$ in May and $7.7^{\circ} \mathrm{C}$ in December. The primary rainy season lasts from June to September and accounts for roughly $70 \%$ of annual rainfall, with August being the wettest month. In April, there is a minor increase in rainfall. According to the Ethiopian National Meteorological Agency (NMAE, 2014), Addis Ababa and its surrounding areas receive $270 \mathrm{~mm}$ of rainfall during the summer months (June, July, and August) and 12 to $32 \mathrm{~mm}$ of rainfall during the winter months (December, January, and February). The study region and the city of Addis Ababa receive an average annual rainfall of (1165 to 1170 $\mathrm{mm}$ ). There is a track in the Entoto Park that separates two major watersheds, the Abbay (Blue Nile) to the north and the Awash to the south, and forms the boundary between Addis Ababa and Oromiya Regions (Figure 2).

\section{Sample site selection}

The data were collected in the field in February of 2016. The field data were collected using a measuring tape meter to lay down sample quadrats along transects at a distance of $50 \mathrm{~m}$ apart. A total of 29 quadrats (with a total area of 2.6 hectares) were sampled (Figure 7). Individuals were classified in a series of girth classes at specific height intervals (Diameter at Breast Height (DBH)) $\geq 3.5 \mathrm{~m}$ high (considered as trees) $1.0 \mathrm{~m}$ to $2.5 \mathrm{~m}$ saplings) and less than $\leq 1.0 \mathrm{~m}$ high (seedlings). With each quadrat/plot positioned along a linear transect at $500 \mathrm{~m}$ intervals, the control transects used in this study reflect the recommended standardized protocol for recording plant distributions and abundances. Each control transect is $1 \mathrm{~km}$ apart and has a quadrat-width of $30 \times 30 \mathrm{~m}$. (Figure 7). The sample plots were placed at a fixed interval $(500 \mathrm{~m})$ on parallel linear transects that were $1 \mathrm{~km}$ apart. For species composition assessment, open space estimation, and bare land cover estimation, one to seven $30 \mathrm{~m} \times 30 \mathrm{~m}$ subplots were formed in each major plot. To collect samples, a mixture of systematic sampling methods was used to set up sampling plots. This method uses a grid superimposed over the survey area to identify stands and subsamples inside stands. At one scale, intersections of north-south and east-west lines identify sampling points within stands, while intersections at a finer scale define stands to be sampled. Eight line transects were laid down starting from the lower limit of the study area to the top of the ridge to investigate the plant community structure, species composition, and regeneration status of Entoto Natural Park Forest. Trees, Seedlings, Saplings, and Shrubs were measured in $30 \mathrm{~m} \mathrm{x}$ $30 \mathrm{~m}$ quadrants. The main $(900 \mathrm{~m}$ square size) plot was sampled for species richness, density, and saplings. Both trees and shrubs rooted in the plot were considered, and Tree Caliper was used to calculate diameter at breast height (dbh) for trees and diameter at stamp height (dsh) for shrubs. Trees and shrubs with a dbh/dsh greater than 2.5 $\mathrm{cm}$ had their height estimated visually. For trees and shrubs with $\mathrm{dbh} / \mathrm{dsh}$ greater than $2.5 \mathrm{~cm}$, the number of stems above ground was also counted and registered. Garmin Mapsource software was used to download the GPS data, which was then processed according to the appropriate method for each data type. Then, using the Forest Genetic Resources Conservation Project (FGRCP) database Access for Windows version7.0 software, percentage cover, frequency, and woody species richness were measured and analyzed.

\section{Data analysis}

All of the data processing was done using different and suitable software depending on the data type. ERDAS Imagine 2014, ArcGIS 10.3, and FGCP were the software packages used. ERDAS Imagine, ArcGIS, MSExcel, and other tools were used to process and analyze geospatial data. A systematic suitability study for biodiversity conservation and ecotourism creation in the Entoto natural park is one of the methodological phases, which is determined using ArcGIS and other software and proper techniques. When used in conjunction with suitable models, GIS may offer a more systematic approach to problem-solving in which both qualitative and quantitative data must be processed (Beedasy and Whyatt 1999). The suitability map analysis was then used to construct GIS vector layers, which were then used as input parameters. The Forest Park's final suitability map was then created in a GIS environment. Since an a priori information was acquired during the field verification of the study area, the imageries were classified using the supervised classification technique. With the aid of ground truth data, pixels that reflect patterns and each land cover feature were identified and selected.

The word "accuracy assessment" refers to comparing the classification to geographical data that is believed to be correct in order to determine the classification process's accuracy. Accuracy assessment should be a critical component of any classification, but it is often overlooked. The reason for this is that it usually involves a lot of work in the field, which can be very expensive and timeconsuming (Congalton 1991).

\section{RESULTS AND DISCUSSION}

The results of field verification revealed that 25 different tree and shrub plant species were discovered in the Entoto natural park, and that the responses to questionnaires and details gathered from personal interviews were nearly identical to the data collected in the field. The plants have already been planted on 500 hectares of the EHT project's 1300 hectares. Furthermore, the Entoto natural park's floristic species compositions are notable, with 20 of them being registered. However, compared to other small Ethiopian forests, the Entoto forest 
had a species diversity of less than 30 tree and shrub plant species. The deforestation of natural vegetation due to population growth and expansion of Addis Ababa city, which began at the end of the 19th century, resulted in a major reduction in plant species in Entoto (Figure 5 and 6).

As shown in two-dimensional plots, the Spectral Profile algorithm revealed that the reflectance values of most vegetation, such as forest, woodland, grass, and shrub, were more separated/de-correlated by Band 5 of Landsat TM (Figure 4). On band 2, however, most feature groups were poorly differentiated, and the reflectance of forest and woodland, as well as shrub and soil, showed subtle differences. As a result, Bands 3, 4, and 5 were identified as insightful and chosen as candidate bands for further investigation. The bands have been plotted in two dimensions (Figure 4).

Then, using a supervised classification system, Landsat data with a resolution of 30 meters for the years 1986, 1995, 2007, and 2015 were graded (Figure 5 and 6). Both GIS and Remote Sensing techniques helped to speed up the testing process, improve accuracy, and cut costs. In addition, an ArcGIS and ERDAS Imagine setting was used to create the study area chart, land use/cover maps, and topographical maps.

The accuracy of classification is usually assessed by comparing the classification with some reference data that is believed to accurately reflect the true land cover (Congalton 1991). The disparity between our classification and the reference data is reflected in the accuracy rating. This table can be used to calculate the overall classification accuracy by calculating how many pixels in the satellite image and on the ground were labeled the same and dividing that amount by the total number of pixels. Land truthing, higher resolution satellite images, and topographical and thematic maps were used as sources of reference data for this research. The classification accuracy of each imagery i.e., 1986, 1995, 2007 and 2015 is 97\%, $90 \%, 82 \%$ and $81.3 \%$ respectively.

\section{Land use land cover change}

The analysis of time-series images from 1986, 1995 , 2007, and 2015 showed that the forest cover of the region increased more in relation to one decadal data by another time data. The other three land cover characteristics do not change spatially. All other characteristics, with the exception of forest cover, are on the decline (Figure 5 and 6 ). According to the results of image analysis, the study's forest area coverage has been steadily increasing in comparison to another vegetal cover from the 1980s to the 1990 s, and from the 1990s onwards, forest cover has been gradually declining while shrub area coverage has increased by more than $1 \%$. (Table 1 ).

The Ethiopian Heritage Trust's environmental protection initiative, which planted 40,000 indigenous seedlings on 500 hectares in the Entoto Natural Park, is also thought to have led to the enhancement of the Entoto forest region. Eucalyptus plantations dominated the entire Entoto mountain range (and much of its surroundings). Forest, bushland, cultivated fields, grassy meadows, rocky slopes and cliffs, lakes, and marshes are among the park's diverse ecosystems. Afro-montane forest and, where drainage is obstructed, woodland with open meadows make up the natural vegetation. Juniperus procera, Olea europaeacuspidata groves, Hagenia abyssinica, Hypericumrevolutum, H.quartinianum, Podocarpus falcatus, and Acacia abyssinica, with A. negrii in some of the more disturbing valleys, would have dominated the area. Erica arborea can be found at elevations of over 3,000 meters.

Fruit-eating birds are drawn to shrubby areas by species like Rosa abyssinica and Carissa edulis, which have fleshy fruits. The number of herbs, both in the forest undergrowth and in the meadows, is enormous, and includes many endemics, including clovers Ethiopian Wildlife and Natural History Society (EWNHS, 2015). Agriculture is one of the mainstays of local residents, who have taken up residence on neighboring lands, including a portion of the Entoto natural park project area, which is being undertaken by EHT. Despite its proximity to Addis Ababa, the surrounding community's farming system has been relatively unaffected by modern inputs (Figure $5 \& 6$ ). Farmers on Entoto grow barley, wheat, and raise cattle and sheep, with some farmers even dabbling in horticulture.

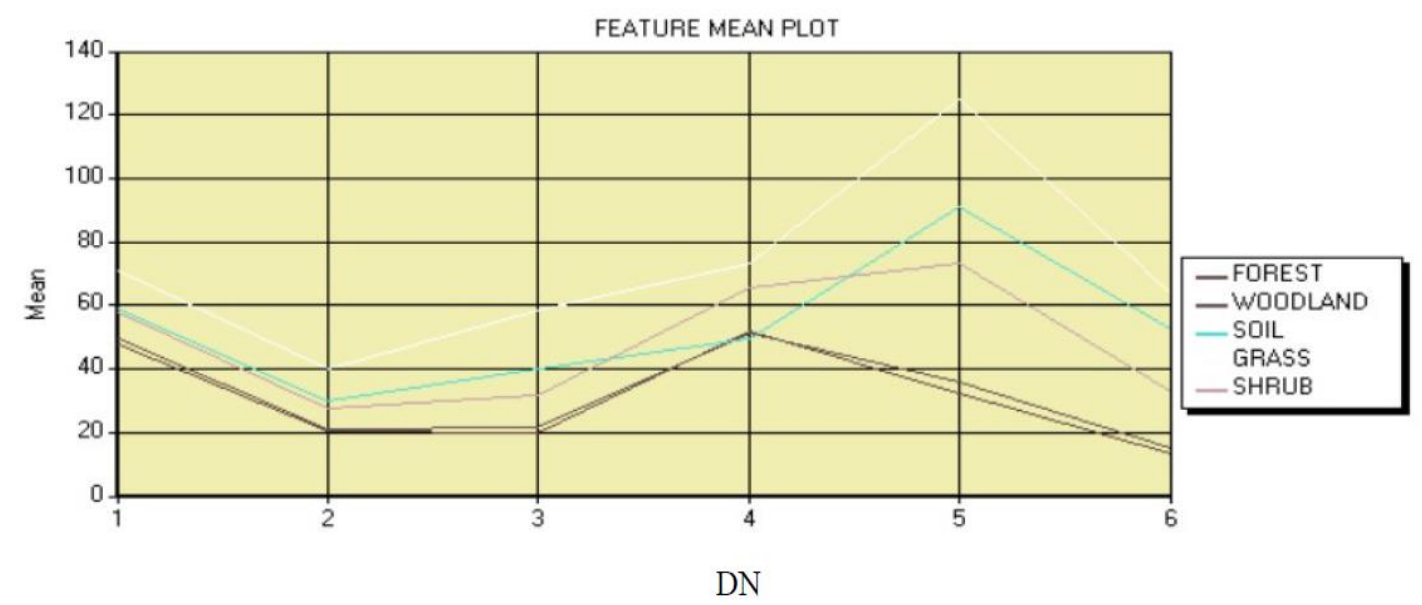

Figure 4. Feature spectrum plot 


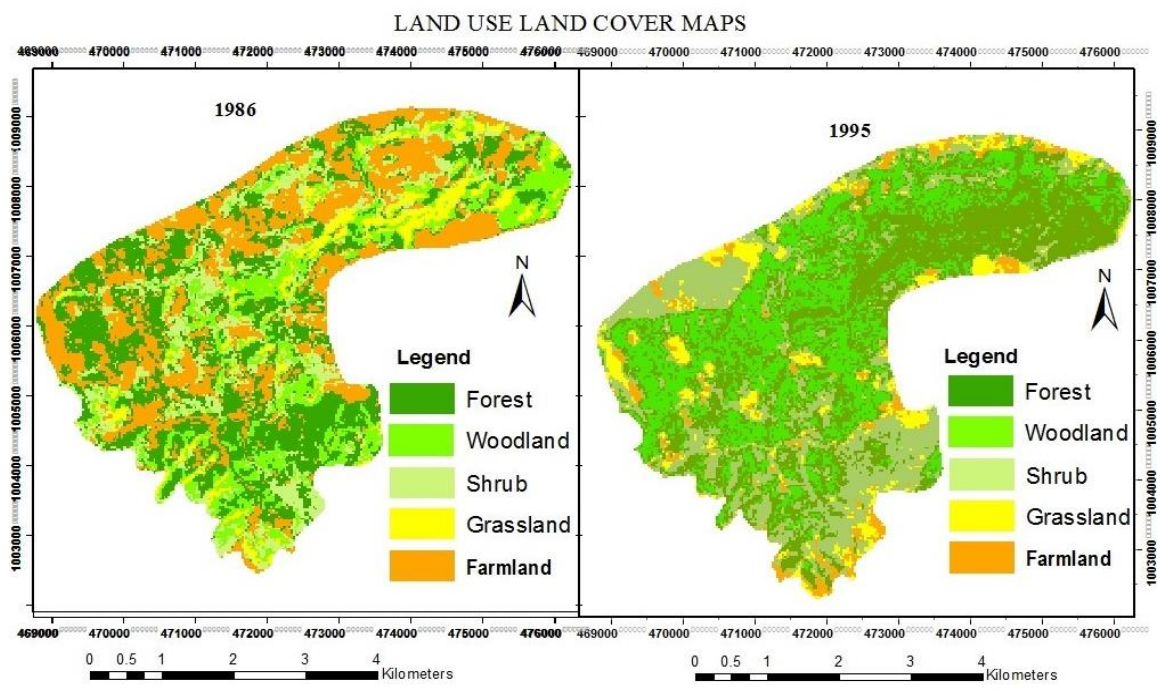

Figure 5. Land use and land cover map of year 1986, (left) and 1995 (right) (Source: Landsat images acquired in 1986 and 1995 )

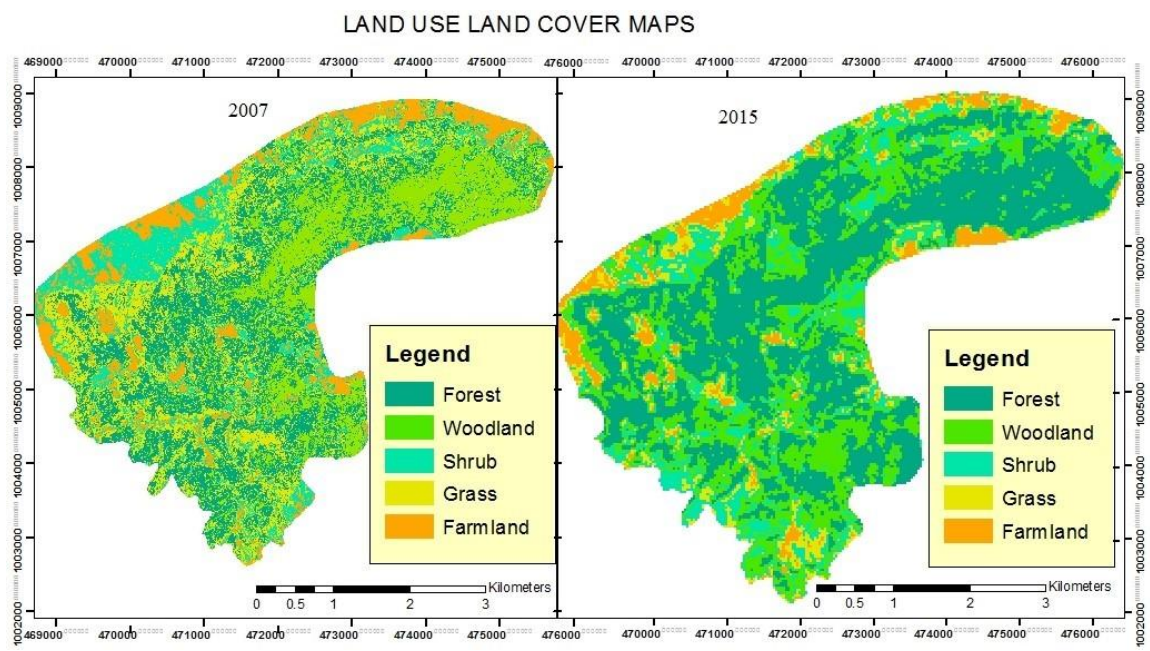

Figure 6. Land use and land cover map of year 2007 (left) and 2015 (right) (Source: SPOT image of 2007 and Landsat image of 2015)

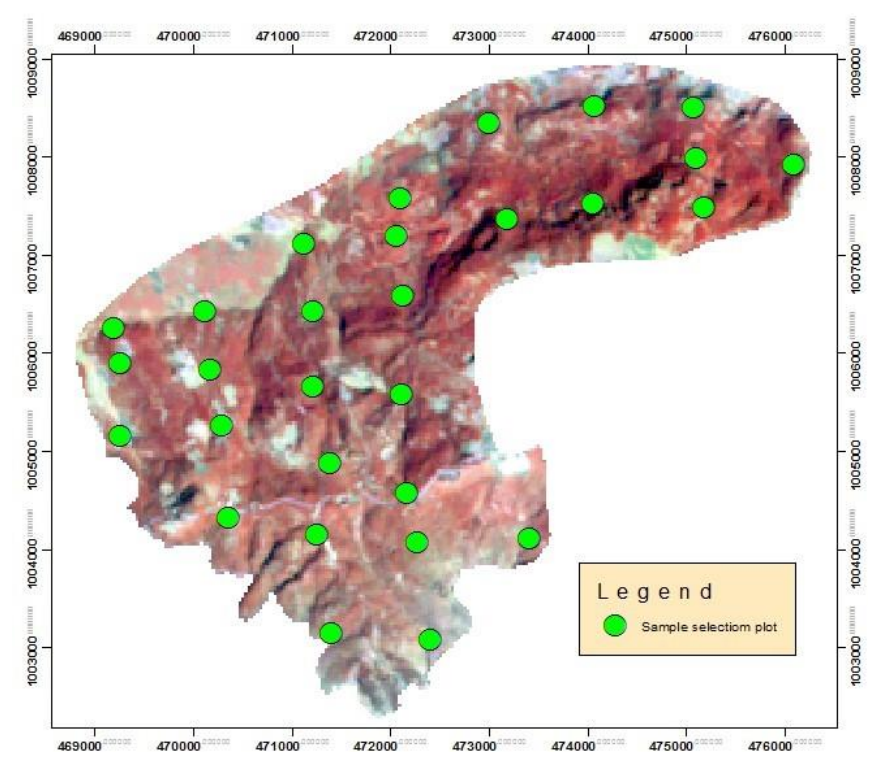

Figure 7. Plots of sample quadrats 
Table 1. LU/cover change in percent

\begin{tabular}{|c|c|c|c|c|c|c|c|c|c|c|}
\hline \multirow{3}{*}{ Year category } & \multirow{3}{*}{$\begin{array}{l}1986 \\
\text { (ha) }\end{array}$} & \multirow[t]{2}{*}{1995} & \multirow{2}{*}{\multicolumn{2}{|c|}{$\frac{\text { B/n } 1986 \& 1995}{\text { Change }}$}} & \multicolumn{3}{|c|}{ B/n $1995 \& 2006$} & \multicolumn{3}{|c|}{ B/n $2006 \& 2015$} \\
\hline & & & & & & & nge & & & nge \\
\hline & & (ha) & (ha) & $\%$ & (ha) & (ha) & $\%$ & (ha) & (ha) & $\%$ \\
\hline Forest & 256.33 & 834.18 & 577.9 & 225.44 & 861.72 & 27.5 & 3.20 & 1085.20 & 223.5 & 25.9 \\
\hline Woodland & 562.6 & 634.41 & 71.8 & 12.77 & 593.20 & -41.2 & -6.95 & 263.12 & -330.1 & -55.6 \\
\hline Shrub & 838.61 & 565.24 & -273.4 & -32.60 & 280.18 & -285.1 & -101.8 & 682.65 & 402.5 & 143.6 \\
\hline Grassland & 111.47 & 156.6 & 45.1 & 40.49 & 235.65 & 79.1 & 33.55 & 95.04 & -140.6 & -59.7 \\
\hline Soil & 531.03 & 109.57 & -421.5 & -79.37 & 329.25 & 219.7 & 66.72 & 174.54 & -154.7 & -47.0 \\
\hline Total & 2300.00 & 2300.00 & & & 2300.00 & Shrub & & 2300.55 & & \\
\hline
\end{tabular}

Table 2. Coordinate points for plots of sample quadrants

\begin{tabular}{lcc}
\hline Plot number & $\begin{array}{c}\text { Easting } \\
\text { (X-Co-ordinate) }\end{array}$ & $\begin{array}{c}\text { Northing } \\
\text { (Y-Co-ordinate) }\end{array}$ \\
\hline 3 & 468549 & 1005401 \\
4 & 472115 & 1005582 \\
5 & 472116 & 1006596 \\
6 & 472058 & 1007189 \\
7 & 472098 & 1007592 \\
4 & 470125 & 1006862 \\
3 & 470175 & 1005830 \\
2 & 470297 & 1005260 \\
2 & 474076 & 1008513 \\
1 & 474063 & 1007522 \\
6 & 471115 & 1007124 \\
4 & 471201 & 1005675 \\
3 & 471383 & 1004874 \\
1 & 470053 & 1004317 \\
1 & 471399 & 1003162 \\
2 & 472997 & 1008345 \\
1 & 473182 & 1007371 \\
1 & 473414 & 1004113 \\
3 & 475072 & 1008501 \\
2 & 475106 & 1007981 \\
1 & 475187 & 1007479 \\
1 & 476095 & 1007923 \\
2 & 471261 & 1004152 \\
1 & 472403 & 1003085 \\
5 & 471115 & 1007124 \\
2 & 472268 & 1004072 \\
3 & 472167 & 1004581 \\
2 & 469289 & 1005701 \\
1 & 469260 & 1005164 \\
\hline & & \\
\hline
\end{tabular}

\section{Assessment of biodiversity}

There were 25 plant species in the study area, including Acacia (2), Junipers (1), Eucalyptus (1), Hagenia (2), Erica (1), Olea (1), Hypericum (1), Podocarpus falcatus (1), Burllesa (1), Domboya (1), Ekebegia (1), Erythrina (1), Ficus (1), Maytenus (1), Millettia (1), Myrica (1), Phoenix (1), Pittosporum (1), Rosa (1), There were 22 trees and three shrubs among them. As a result, only 25 plant species from 20 families were included in the research plots. The quantitative study was focused on 22 of these 25 species, which were woody plants (trees and saplings). Trees are the most common growth type among woody plants, accounting for more than $80 \%$ of the total. The field data, including plant measurement data, plot points, and their location/coordinates, were analyzed, and the outputs were produced. The plot points that resulted were combined and overlaid on the image map of the sample selection region (Figure 7).
Table 3. Floristic richness of the Entoto Forest, Ethiopia

\begin{tabular}{|c|c|c|c|c|}
\hline No. & $\begin{array}{c}\text { Forest } \\
\text { name }\end{array}$ & $\begin{array}{c}\text { Genus } \\
\text { name }\end{array}$ & $\begin{array}{c}\text { Species } \\
\text { name }\end{array}$ & Family name \\
\hline 1. & Entoto & Acacia & abyssinica & Fabaceae \\
\hline 2. & Natural & Acacia & negrii & Fabaceae \\
\hline 3. & Park & Burollesa & polystachya & Dioscoreaceae \\
\hline 4. & & Domboya & torrida & Sterculiaceae \\
\hline 5. & & Ekebegia & capensis & Meliaceae \\
\hline 6. & & Erica & arborea & Ericaceae \\
\hline 7. & & Erythrina & brucei & Fabaceae \\
\hline 8. & & Eucalyptus & globulous & Myrtaceae \\
\hline 9. & & Ficus & sycomorus & Moraceae \\
\hline 10. & & Hagenia & abyssinica & Rosaceae \\
\hline 11. & & Hygenia & abyssinica & Rosaceae \\
\hline 12. & & Hypericum & revolutum & Hypericaceae \\
\hline 13. & & Juniperus & procera & Cupressaceae \\
\hline 14. & & Maytenus & arbutiolia & Celastraceae \\
\hline 15. & & Millettia & ferruginea & Fabaceae \\
\hline 16. & & Myrica & salicifolia & Myricaceae \\
\hline 17. & & Olea & europaea & Oleaceae \\
\hline 18. & & Phoenix & reclinata & Arecaceae \\
\hline 19. & & Pittosporum & viridiflorum & Pittosporaceae \\
\hline 20. & & Podocarpus & falcatus & Podocarpaceae \\
\hline 21. & & Prunus & africanus & Rosaceae \\
\hline 22. & & Rosa & abyssinica & Rosaceae \\
\hline 23. & & Salix & subserata & Salicaceae \\
\hline 24. & & Schefflera & abyssinica & Araliaceae \\
\hline 25. & & Syzygium & guineense & Poaceae \\
\hline
\end{tabular}

Source: data recorded by Author

Understanding the variation in plant diversity patterns of different scales is an important topic and crucial for both ecological explanations and for effective conservation design (Devries et al. 1997, as cited in Lema 2011). The description of plant communities involves the analysis of plant diversity, evenness and similarity (Whittaker 1960). A GPS was used to record the positions (coordinates) of each sample map. The information needed for this study came from a number of places. Various references, studies, and blogs were helpful in learning about existing policies, programs, projects, best practices, and so on. The plot point coordinates were also arranged in a tabular format (Table 2).

The diversity and equitability (evenness) of species in a given plant population are used to interpret relative differences between and within the community, and to help understand the key explanation for such differences. According to the United Nations, species diversity has been described as one of the main indices of sustainable land-use 
practices, and significant resources are being spent to identify and enforce strategies that will reverse the current decline in biodiversity at local, regional, and global scales (Shackleton 2000). Other forests were chosen for comparison and then addressed. Floristic Composition

\section{Entoto Natural Park}

During field data collection in the Entoto evergreen forest, a total of 25 plant species were registered and used for study (Table 1). This demonstrates that Entoto Park lacks species diversity in comparison to many other Ethiopian forests, where over 80 tree plant species have been described in each area. Previously, Juniperus procera has dominated the forest, with groves of Olea europaea cuspidata, Hagenia abyssinica, Hypericum revolutum, $H$. quartinianum, Podocarpus falcatus, and Acacia abyssinica scattering through, and with A.negrii in some of the more disturbing valleys. Erica arborea can be found at elevations of over 3,000 meters. Fruit-eating birds are drawn to shrubby areas by species like Rosa abyssinica and Carissa edulis, which have fleshy fruits. The number of herbs, both in the forest undergrowth and in the meadows, is enormous, and includes many endemics, especially clovers. However, during fieldwork, it was discovered that the majority of the Entoto mountain range (and many others nearby) is covered in Eucalyptus plantations, followed by Juniperus procera trees. The data analysis revealed that the majority of the plant species found in the study plots are native to the region (Table2). Based on the data of the plant species, the FGRCP database Access for Windows version software was used to classify the vegetation into plant population types. The FGRCP database Access for Windows version7.0 software was then used to analyze field data, calculating and determining floristic richness, plant density, frequency, density per forest, and total stem per forest.

The number of stems reported in each quadrant was measured, and Eucalyptus globulus is the most abundant, accounting for 4560 stems in all quadrants, while Podocarpus falcatus is the least abundant, accounting for just 15 stems and $0.17 \%$ of the total stems (Table 5). In all quadrants of the forest vegetation, a few tree species dominated the number of stems, with Eucalyptus globulus species accounting for nearly half of the overall abundance. Eucalyptus globulus and Juniperus procera, two tree species, accounted for nearly $88 \%$ of the total species abundance in the region (Table 4).

Just two species were found in more than $88 \%$ of the plots, indicating that the forest was dominated by a limited number of species. With one species each, the Myrtaceae and Cupressaceae families are the most diverse, followed by the Oleaceae family. Myrtaceae is the most abundant plant in terms of stand density (Table 5).

Table 4. Quantity of stems in all quadrants

\begin{tabular}{|c|c|c|c|c|}
\hline $\begin{array}{l}\text { Forest } \\
\text { name }\end{array}$ & $\begin{array}{l}\text { Genus } \\
\text { name }\end{array}$ & $\begin{array}{l}\text { Species } \\
\text { name }\end{array}$ & $\begin{array}{l}\text { Sum of } \\
\text { quantity }\end{array}$ & $\%$ \\
\hline 1 & Acacia & Negrii & 168 & 1.907 \\
\hline 2 & Acacia & Abyssinica & 118 & 1.339 \\
\hline 3 & Burollesa & polystachya & 75 & 0.76 \\
\hline 4 & Domboya & Torrida & 52 & 0.53 \\
\hline 5 & Ekubeergia & Capensis & 9 & 0.09 \\
\hline 6 & Erica & Arborea & 870 & 9.875 \\
\hline 7 & Erythrina & Brucei & 84 & 0.853 \\
\hline 8 & Eucalyptus & Globulous & 4560 & 51.759 \\
\hline 9 & Ficus & sycomorus & 96 & 0.98 \\
\hline 10 & Hagenia & Abyssinica & 160 & 1.816 \\
\hline 11 & Hypericum & Revolutum & 150 & 1.703 \\
\hline 12 & Hypericum & Revolutum & 65 & 0.66 \\
\hline 13 & Juniperus & Procera & 2432 & 27.605 \\
\hline 14 & Maytenus & Arbutiolia & 51 & 0.52 \\
\hline 15 & Millettia & Ferruginea & 93 & 0.94 \\
\hline 16 & Myrica & Salicifolia & 85 & 0.86 \\
\hline 17 & Olea & Europaea & 337 & 3.825 \\
\hline 18 & Phoenix & Reclinata & 37 & 0.38 \\
\hline 19 & Pittosporum & viridiflorum & 49 & 0.50 \\
\hline 20 & Podocarpus & Falcatus & 15 & 0.17 \\
\hline 21 & Prunus & Africanus & 57 & 0.58 \\
\hline 22 & Rosa & Abyssinica & 91 & 0.92 \\
\hline 23 & Salix & Subserrata & 55 & 0.56 \\
\hline 24 & Schefflera & Abyssinica & 63 & 0.64 \\
\hline 25 & Syzygium & Guineense & $\begin{array}{l}72 \\
9844\end{array}$ & 0.73 \\
\hline
\end{tabular}

Table 6. Quantity of plant species of different forests

\begin{tabular}{lc}
\hline \multicolumn{1}{c}{ Forest name } & $\begin{array}{c}\text { Total number of species per } \\
\text { forest }\end{array}$ \\
\hline Entoto Natural Park & 25 \\
Menagesha suba Forest & 128 \\
Boginda Forest & 73 \\
Belete Forest & 157 \\
\hline
\end{tabular}

Table 5. Relative density of the plant

\begin{tabular}{lllccc}
\hline Forest name & Genus name & Species name & Total stems & Total stem per forest & Relative density \% \\
\hline Entoto Natural Park & Acacia & abyssinica & 17 & 0.08 \\
& Erica & arborea & 279 & 1.3 \\
& Eucalyptus & globulous & 15359 & 88 & 70.21 \\
& Hagenia & abyssinica & 6106 & & 0.41 \\
& Juniperus & procera & & 21570 & 28.00 \\
& & & & 100 \\
\hline
\end{tabular}




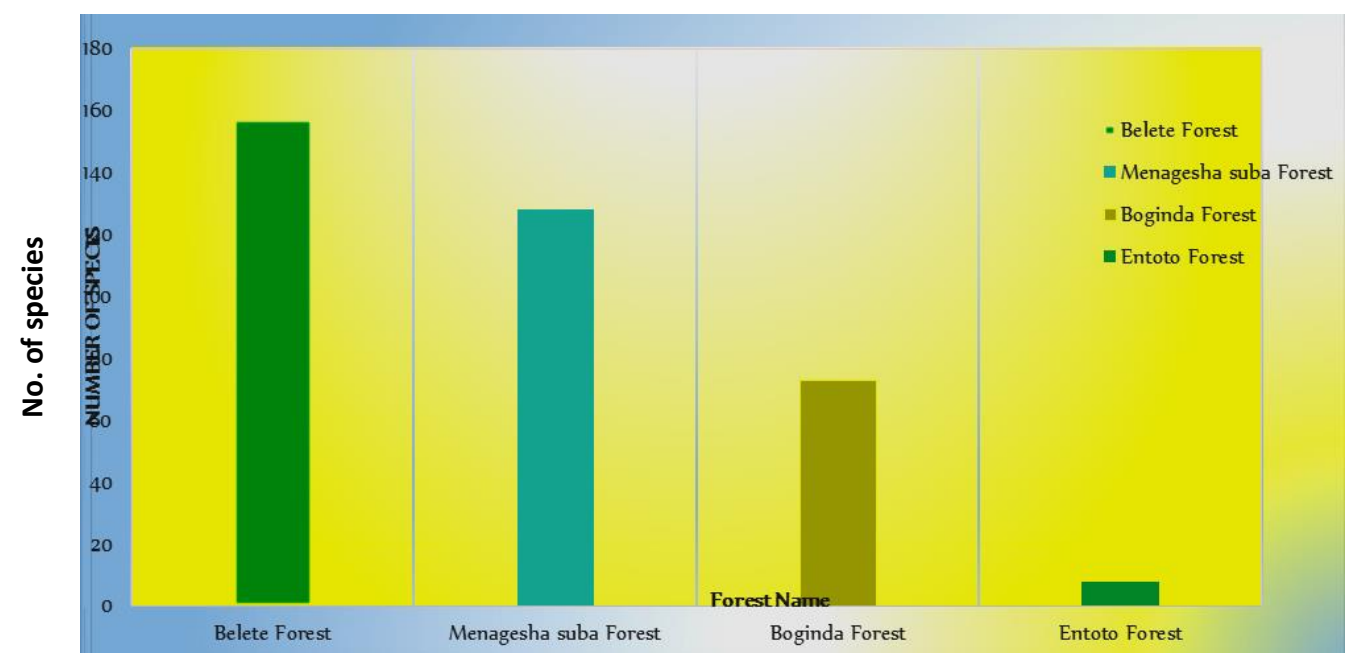

Forest name

Figure 8. Comparison of forest floristic richness

\section{Menagesha suba state forest}

The Menagesha Suba State Forest is $30 \mathrm{~km}$ southwest of Oromia National Regional State in central Ethiopia. The mountainsides are generally steep with ravines cut by streams and rivers. The Menagesha Suba State Forest has a total area of 9,248 hectares. The Ethiopian plateau was once thought to be covered in a vegetation mosaic of dry evergreen Afromontane forest, grassland, and Acacia woodland. Forests and woodlands grow on the well-drained soils of the mountains and valley sides, while grassland grows on the thick clay soils of the bottoms of valley. The Natural Forest of Menagesha Suba State Forest is dominated by Juniperus procera, which grows to c. $30 \mathrm{~m}$ and has a relatively open canopy, according to (Lema 2011). The understory is made up of Olea europaea subsp cuspidata, Allophyllus abyssinicus, Maytenus arbutifolia, and Euphorbia ampliphylla, with a few Podocarpus falcatus trees strewn around. Juniperus procera, Erica arborea, Rosa abyssinica, and the endemic Jasminum stans coexist at higher elevations. Lobelia giberroa and Solanecio gigas, two giant herbs, dominate the valley sides, while Scadoxus multiflorus carpets the forest floor. The floristic data analysis was based on 106 species included in the sampled plots. Menagesha Suba State Natural Forest has a total of 128 species of herbaceous flowering plants, divided into 102 genera and 44 families (Lema 2011).

\section{Boginda forest}

Boginda forest spans 7500 hectares of natural high forest and is administratively located in Gimbo Woreda, Kafa-Shaka Zone, Southern Nations, Nationalities and Peoples Region. Boginda forest yielded a total of 73 woody specimens, 70 of which were inside the sample plots and three of which were outside the sample plots. Rubiaceae was the forest's most diverse genus, followed by Euphorbiaceae, Celastraceae, and Fabaceae.

\section{Belete moist evergreen montane forest}

Belete forest is located 375 kilometers southwest of Addis Ababa in the Shabe-Sombo District, Jimma Province, Oromia National Regional State. A total of 157 species of vascular plants belonging to 135 genera and 69 families were described in the Belete moist evergreen montane forest (Gebrehiwot and Hundera 2014). Pteridophytes and gymnosperms were described by two species each, while Angiosperms accounted for the remaining 153 species. The gymnosperms Podocarpus falcatus and Juniperus procera were found in the study field. With ten and nine species, respectively, the Fabaceae and Lamiaceae families had the most species. One species was assigned to each of the thirty-three families. Herbs dominated the growth forms of the species reported from the Belete moist evergreen montane forest, followed by trees. The Belete moist evergreen montane forest contains $17(10.82 \%)$ Ethiopian endemic species, some of which are included in the Ethiopian endemic species list (Kflay and Kitessa 2014). The total number of plant species found in Entoto Natural Park, Menagesha Suba State Forest, Belete Moist Evergreen Montane Forest, and Boginda Forest were used as a comparison (Table 5) and the data were presented graphically (Figure 8).

\section{Suitability analysis for ecotourism development}

Since the Entoto natural park is not yet a fully-fledged national park, it is not under the control of the Addis Ababa City Administration's Culture and Tourism Bureau or the Ministry of Culture and Tourism, but rather of the Addis Ababa City Administration's Environmental Protection Bureau (EPB). The Entoto Natural Park is currently in the process of becoming a wildlife-filled, visitor-ready tourist attraction, and it is only a conservation project now. The Entoto natural park's flora and fauna are not what attract visitors. According to Tesfaye (2009), this is because it is dominated by (originally Australian) Eucalyptus globulous trees, which kill other vegetation. The Ethiopian Heritage Trust project is starting to yield results. The attractive, 
rugged hillside above Entoto Natural Park's nursery, complete with a diverse range of indigenous plants, stands in stark contrast to the lifeless, uniform eucalyptus swaths. It gives visitors a sense of what the landscape was like before Addis; and the restoration has resulted in the return of dik diks, duikers, and jackals, as well as a number of birds and shrubs like Rosa abyssinica. Students and visitors flock to the park because of its scenic beauty, which includes waterfalls, hills, and a variety of birds. The Trust intends to develop restaurants, playgrounds, and a training center for students interested in natural history in the future. The local population can acquire new skills, allowing them to become less reliant on limited natural resources.

The suitability of Entoto Natural Park for ecotourism creation was assessed using selected parameters and geographic information systems (GISs) methods in this report. A simple self-assessment method for determining the suitability of a proposed ecotourism operation is the site suitability assessment. When determining suitability, environmental degradation is taken into account. For example, there may be land uses that appear to be highly productive in the short term but are more likely to result in soil erosion, progressive pasture depletion, or downstream river regime changes. Such consequences would outweigh the short-term gains, and the property would be classified as unfit for such uses. This theory does not imply that the ecosystem should be maintained in its original state. What is expected is that the likely environmental impacts of any planned land use be evaluated as accurately as possible, and the assessments be taken into account when assessing suitability (Pareta 2013).

Distance from roads, land use/cover, reservation/ protection, species diversity, elevation and slope, proximity to settlement centers, and population size were all factors considered during the assessment process for the ecotourism site. In terms of settlement sites, the park is close to Addis Ababa region, Sululta town, Chancho in the north, Burayu, Menageha, Sebeta towns in the west, and Lagatafo-lagadadi in the east, as well as all other Addis Ababa satellite towns. Those factors were chosen based on the technical expert's recommendations. An effort was made to look at the specifics of the causes. The proposed methodology was useful in identifying ecotourism sites by linking important parameters to the actual resources of the studied region. The site should be: (i) At least 1000 meters from densely populated areas. (ii) Within 1500 meters of an existing all-weather, dry-weather, and motorway route. (iii) Definitely not on farm ground. (iv) Certainly not on community-owned land. (v) Traditional owners and local communities should be involved and benefited.

The analyses were primarily focused on the parameters mentioned above. The results of the analysis revealed that the Entoto natural park met the criteria for being recommended as a suitable site for ecotourism production. In general, the following factors were established and used as indicators of suitability within land ecosystems in this study:

Accessibility and distance from roads: Access characteristics were displayed in terms of road access, with road categories (all-weather road, dry weather road, and motorways) taken into account.

Dense residential area: it was determined that the study area is located beyond a radius of 1000 meters from densely populated areas.

Landscape: The park is located on elevated ground above Addis Abeba, with attractive, wider visibility and the rugged hillside of the Entoto ridge.

Biodiversity: The Ethiopian Heritage Trust's environmental conservation project activity planted 40,000 indigenous seedlings in the Entoto Natural Park, covering 500 hectares of parkland. The Ethiopian Heritage Trust project planned to plant 44,000 indigenous seedlings in the near future and to completely cover its project area with indigenous plant species.

Topography: it is located on the top of Entoto Mountain, with excellent visibility (Figure 3).

Telecommunications: It was revealed that the study area is surrounded by a well-developed telecommunication infrastructure.

Power supply: within a $1000 \mathrm{~m}$ radius of the study area, there is a well-developed and adequate sub-station infrastructure.

Population size: the park is situated on the outskirts of Addis Ababa's city limits in terms of settlement centers. Other nearby towns include Addis Alem, Sululta, and Chancho in the north, Burayu, Menageha, and Sebeta in the west, and Lagatafo-lagadadi in the east, as well as Bushoftu, Dukem, and Akaki in the south. A buffer zone was established around the proposed site in terms of dense residential areas and industrial zones, meaning that it will not be too close to already heavily populated areas or existing tourist zones. It was determined that no location could be built on agricultural land or community-owned property.

The suitability of a piece of land is determined and graded based on the type of usage it may receive. This theory expresses the understanding that different types of land use have different requirements. The characteristics of each type of land are compared to the requirements of each usage, such as moisture availability or flooding risk. As a result, both the property and the land use are equally important in determining land suitability (Queensland State (2015). A collection of requirements is needed for almost all development issues. Similarly, the development of ecotourism necessitates the development of a set of parameters that can be used to select ecotourism sites in order to validate the current opportunities and challenges. In order to assess tourism alternatives, certain environmental impacts such as air quality, surface water quality, groundwater quality, road traffic, noise level, solid waste disposal system, archaeological and historical sites, natural vegetation, and wild animal life were recommended in the literature (McIntyre et al. 2006).

\section{Discussion}

\section{Opportunities}

Some interventions, involving ecotourism activities, have been attempted in Adaba-Dodola forest priority area in Bale zone in Oromia regional state. WAJIB, which is 
said to be "Waldaa Jirattoota Bosonaa" in Afan Oromo meaning "forest Dwellers associations" is an example of such effort. Safe areas are now used to preserve wildlife and natural habitats on a wide scale. However, these protected areas are constantly confronted with a variety of issues. There could be both a threat to and an opportunity for natural resource protection in these protected areas (Wearing and Neil 1999). Ecotourism has been implemented in some countries' protected areas to address these issues, as ecotourism has the potential to play a major role in natural resource management and overall growth in developing countries (Strasdas 2002). To improve the quality of human life, there is a growing need and opportunity to build bridges between these two systems. Only by linking our formal knowledge system, which is based on a hypotheticaldeductive approach and inductive reasoning to understand ecosystems, with the conventional knowledge system, which is derived from societal interactions and beliefs, can we understand the dynamic relationships that occur between ecological and cultural systems. Traditional ecological awareness, such as medicinal plants and local food organisms, has a reasonably well-developed understanding of tangible benefits. However, we need to improve our understanding of the connections between ecological and social processes, as well as their tangible and intangible benefits (such as spiritual and religious values), and their effect on sustainable natural resource management at the landscape level (Rudolf et al. 2003). A concurrent trend in development is the discovery of land uses that are both environmentally and economically viable. The World Commission on Environment and Development (WCED, 1987) established and promoted "sustainable development" as the umbrella under which these efforts take place (Langholz 1996).

Traditional and formal information structures must be connected to achieve ecosystem protection and sustainable use. There is a growing need and potential to create bridges between these two structures in order to enhance human life quality (Rudolf et al. 2003). People are becoming more overweight as a result of more sedentary lifestyles, putting them at risk for chronic diseases like diabetes earlier in life. There is a growing recognition that health systems will be unable to cope unless a corresponding shift to more healthy lifestyles occurs. Parks are excellent locations for getting some good exercise (Barber 2008). Urban green spaces, according to Arvaniditis (2008), offer opportunities for exercise and leisure, contributing to people's physical and mental health. Green spaces have also been shown to be beneficial to human physical and mental health, according to Kazmierczak and James (2008) as cited in (Mesfin 2011). Visiting a national park or a protected area contributes to the park's upkeep by paying fees to the staff who look after it.

Ecotourism is a form of tourism that places a strong emphasis on environmental and cultural preservation. Forests provide social benefits such as wellness, employment, education, leisure, community building, and land (Kuchelmeister 2000). These advantages are often ignored. For a developing country like Ethiopia, job benefits are especially important, while other social benefits will become more important as living standards rise. Ecotourism development entails expenses, most notably a budget for environmental protection, treatment, and management. Although the budget required is substantial, the long-term benefits will usually outweigh the costs. Other costs could include risks to human safety, structural harm, vandalism, unorganized waste disposal, and solar energy reduction. These costs, however, can be reduced by taking the right steps. Ecotourism benefits the local community by creating jobs, providing services, and stimulating the economy. It conserves resources and protects plants and animals from the negative effects of conventional tourism (Carter 1995).

The followings are some of the importance of ecotourism: (i) The expansion of the ecotourism industry would provide jobs for local residents and ensure that fewer people migrate to towns. (ii) You will appreciate the handiwork of local artisans, and purchasing from them would support their economy while also preserving the local heritage. (iii) It is low-impact tourism, in which visitors make a deliberate effort to respect the environment, conserve natural resources, and re-invest a sufficient portion of their earnings in environmental protection. (iv) Ecotourism will bring you closer to nature, open your mind to fresh ideas, take you to less-traveled areas, and provide you with a memorable new experience while minimizing environmental impact. (v) You can watch birds or take a walk through forests to explore the various natural wonders and stop by the villages to enjoy their cuisine and lifestyle.

Ethiopia received a five-year USAID (United States Agency for International Development) grant to support the country's ecotourism development after many homegrown Ethiopian ecotourism associations sprang up in the early 20s (Logan 2012). One important factor behind this trend is that there is substantially more tourism-related work being done around the organization and in different regions; evidence indicates that demand for lending and advice is growing in tandem with the political economy and tourism growth in developing countries (Mann and Hawkins 2006). Experts founded the Ethiopia Sustainable Tourism Alliance (ESTA) with grant funding to communicate with local communities and collaborate on the development of local ecotourism enterprises (Logan 2012). ESTA is a member of the USAID Global Sustainable Tourism Alliance, which uses tourism production to alleviate poverty, promote economic growth, promote environmental stewardship, and protect biodiversity in a variety of countries around the world. In Ethiopia, the Alliance is already collaborating with local stakeholders to develop a program that will build employment, protect the environment, and respect socialcultural values and heritage. Biodiversity protection, ecotourism and other niche business creation, workforce development, and handicraft production and marketing will all be part of the program. ESTA is focusing on the Central and Southern Rift Valley Lakeland in order to protect and improve both biodiversity and cultural patrimony. The Rift Valley Lakeland, home to the popular ESTA development in Lepis and the earlier German Agency for International Cooperation (GIZ) development in Adaba Dodola, is rich in nature preserves and historic lakes. ESTA brought 
community members from Lepis to see what they could do with their region after GIZ built rustic accommodations in Adaba Dodola, and worked with them to pick possible campsites within the forest and identify exotic bird species that would appeal to the lucrative bird-watching tour market. Locals took the initiative to upgrade forest trails and build a river bridge to expand hiking opportunities. A 15-unit lodge with rustic reed-and-grass huts is operated by Village Ethiopia, an Ethiopian-owned tour company in the area. Despite the fact that Africa was the only place in the world to see a rise in international arrivals in 2009, at the height of the global recession, Ethiopia has been slow to reap the benefits of this international interest, attracting only $0.7 \%$ of the continent's tourists, according to the United Nations. (http://www.irrob.org/ecotourism _in_ethiopia.html_Ecotourism in Ethiopia. EhiopianJournal).

The Ethiopian Heritage Trust (EHT) was established in 1992 by a group of patriots including Architect Yosef Bereded, Dr. Agidew Rede, Prof. Richard Pankhurst, Dr. Alula Pankhurst, Michael Sergeant (British nationality), and a few others with the aim of preserving and developing Ethiopia's historical, cultural, and natural heritage. Aside from tourism income, there has always been a trade-off between economic development and environmental conservation in the past. Green growth, or investing in renewable energy sources, has only recently become a mainstream concept. This trade-off has been and continues to be, even more, pronounced for a developing country like Ethiopia, where economic growth is the primary goal of policy. A long-term conservation project is underway on the outskirts of Addis Ababa to restore indigenous vegetation in place of the introduced eucalyptus that has dominated for over a century (William 2009). However, with the current focus on climate change issues and the broader concept of sustainability, environmental considerations have become commonplace. As these philosophies are coupled with romantic, aesthetic ideas about the protection of original ecosystems and organisms, a powerful concept emerges: not only is it good to conserve rare, natural objects, but we also need to be far more vigilant about how we use the earth's resources (William 2009). Resource evaluation, creation of management plans for forest management and land use, and organizing local communities around parks and consumers of non-timber forest products are among the successful actions that have been carried out in most of Ethiopia's national regional states since 2010. The annual economic benefit of certain protected areas is projected to be 1.5 billion dollars in direct and indirect terms. "Both the land and the communities in the destination must be safe and prosperous for tourism to be profitable and sustainable." (http://ethiopia.usembassy.gov/pr_5.html)

The following are a few examples of ecotourism development opportunities: (i) The Ethiopian Heritage Trust's long-term conservation project to preserve indigenous plants and protect the ecosystem, as well as their ongoing monitoring. (ii) The park's position on the outskirts of Ethiopia's capital, Addis Ababa, as well as its geographical location in the heart of the country. (iii) Proximity to several urban centers that are potential stakeholders/visitors in the future, especially Addis Ababa, Ethiopia's capital and largest city. (iv) The park is along the main road from the central part of Addis to the city and can also be reached from other directions by the all-weather route. (v) The site may be accessed through existing roads and tracks without incurring maximum road construction costs. (vi) The forest has been constantly being protected from human, domestic and wildlife destruction.

\section{Challenges}

Furthermore, as demand for ecotourism grows, the availability of suitable ecotourism sites around the world is dwindling, jeopardizing their ecological viability. Incompatible economic uses of land area for other economic activities such as agriculture, industry, mining, and urban development, inappropriate tourist development and infrastructures necessary to support that development, willful destruction of ecotourism by tourists, numbers of tourists in excess of carrying capacities, and adverse environmental conditions are the main reasons for the deterioration of ecotourism sites (Tisdell and Wilson 2005). While the ecotourism industry has experienced significant growth in the last several years in terms of arrivals and offers, visitors still see the parts of the country being developed for ecotourism. It's difficult to reach Ethiopia's total glut of unspoiled natural areas independently with infrastructural concerns remaining one of the main unaddressed barriers to rural tourism (Logan 2012). In developing countries, natural resources are under considerable threat, partly due to lack of alternatives and partly because of people's livelihoods. By diversifying people's livelihoods (mainly to an environmentally friendly nature), pressure on natural resources can be minimized. Ecotourism enables the diversification of livelihoods and the sustainable management of natural resources as an economic activity In this context (Amogne 2014). The link between protected areas and the local communities is a key element in the sustainable preservation of natural resources within and around these protected areas, Okello (2003) noted. In many cases, however, there are conflicts between relations. Public participation can encourage the transfer of knowledge between park management and local communities, which can stimulate mutual understanding between concerned stakeholders.

Land scarcity as a result of population pressure, inequitable land allocation by non-local communities, and a lack of accountability in dealing with land issues can all lead to conflict. Some land disputes are caused by global factors such as trade liberalization, structural reform programs, commercialization, imperialism, and the privatization of collective lands, forests, and water services (AUC-ECA-AfDB 2010). Inequitable income sharing arises from inadequate involvement of locals in the ecotourism growth process. The simple provision of incentives as a means to exploit resources and marginalize a certain segment of a population may increase resource exploitation, loss of trust in ownership, and marginalized community frustration with ecotourism production (Teressa 2015). 
The study's findings revealed/ confirmed that the Entoto Natural Park offers both crucial opportunities and challenges for ecotourism growth. Some of the recent challenges are: (i) One of the recurring disagreements between the EHT project and the surrounding community (farmers) in the Entoto park area, as described by EHT experts, revolved around access to and control over property, primarily timber, farmland, and land for house settlement. (ii) The orthodox church's repeated demand for possession of the eucalyptus trees. (iii) Deforestation, clearing of all-natural trees, and the dominance of only a few exotic plant species diversity, which is not favorable for many animal species as a habitat and has less biological diversity than many other forests. (iv) Anthropogenic practices include removing vegetation from cities, soil degradation, and population pressure. (v) Wildlife and domestic animals destroy the saplings planted by the EHT project. (vi) Unreliable budget source for indigenous plant protection and restoration, as well as trouble obtaining tourism funds. (vii) Invasive Alien Species (IAS) is the second most important cause of ecosystem change after climate change. Eucalyptus globulous is one of the Invasive Alien Species, according to Mack et al. (2007). (IAS). Unfortunately, the (originally Australian) E. globulous trees dominate Entoto Park, suppressing other vegetation.

By altering biogeochemical cycles, the existence of IAS in an ecosystem can influence its functioning across a broad range of temporal and spatial scales (Mack et al. 2007). Eucalyptus globulous is one of the Invasive Alien Species, according to Mack et al. (2007). (IAS). Unfortunately, the (originally Australian) E. globulous trees dominate Entoto Park, suppressing other vegetation. Eucalyptus species have been introduced since 1895 to meet the demand for wood fuel, building materials, and to relieve pressure on remaining natural vegetation. It is unlikely that Addis Ababa would have been Ethiopia's capital and Africa's diplomatic center if Emperor Menelik II had not succeeded in introducing Eucalyptus (Hancock 1995). A greenbelt was built around the city as a result of the massive reforestation campaign, which solved the everpresent problem of wood scarcity. Since 1925, Acacia 'Eucalypt polis,' or eucalyptus tree city, has been extended, as has this greenbelt. The plantation area around Addis Ababa, including Entoto ridge, was about 13,500 to 15,000 ha in the 1960s and 1970s. Unfortunately, the fast-growing, water-sucking tree is jeopardizing the ecosystem's biodiversity. While trees have always been a significant part of human settlements, their true importance to city dwellers has only recently been recognized. The importance of trees and green spaces in enhancing city living conditions cannot be overstated. Government and foreign funding for urban forestry has been minimal in most developing countries. The rapid rise in urban population in these countries, along with related increases in food, fuel, and shelter needs, necessitates the development of strategies in which forestry plays a larger role in supplying these resources and improving the urban living environment (www.ecotourism.org/ties-overview). The "fuel-wood problem," "social forestry," and, most recently, the protection of biological diversity and mitigating global climate change have all become frontpage news. However, forestry has remained a rural practice in the eyes of the public, despite its broadened goals. The struggle of growing populations to meet their needs for food, electricity, and construction wood has resulted in environmental degradation in towns, peri-urban areas, and even accessible rural areas (Kuchelmeister and Braatz 2000). This is also true of Addis Ababa, Ethiopia's capital. Furthermore, because of resource conflict, local views of protected areas are negative. They saw conservation areas as a hindrance to their land use. People who live near protected areas have survival needs that are diametrically opposed to the park's needs. The process of involving local people in decision-making and park management activities was not given enough consideration. Local residents, on the other hand, are blamed by conservationists as a significant obstacle to the protected area's conservation. As a result, in order to maintain protected areas through the creation of ecotourism, which heavily involves local people in decision-making and profit sharing, it is important to collaborate with local people. Addis Ababa requires ecotourism development strategies and plans that adhere to sustainable ecotourism development principles such as the active contribution of the sub-sector to the protection of environmental, historical, and cultural heritage, as well as the participation of local and indigenous communities in its planning, development, and activity, which benefits their well-being. To end this other, the proposed guidelines are expected to make a major contribution in the future to fostering sustainable ecotourism growth in and around Addis Ababa. Communities, government partners, and the private sector collaborated to develop long-term, marketdriven attractions that enable residents to benefit from environmental and cultural preservation (Jennifer 2013).

Various schemes to rebuild and rehabilitate degraded areas in Ethiopia are also being led by the Ethiopian Ministry of Agriculture. Area closure, integrated community-based watershed protection, and natural forest management are among the plans. The Ethiopian Heritage Trust has embarked on a project to plant indigenous seedlings in Entoto (north of Addis Ababa) in order to preserve indigenous ecosystems and establish a natural park, with students voluntarily participating. To direct considerations for the construction of ecotourism facilities on national parks as outlined in the implementation process, the Queensland State of Australia has defined the following Practice Criteria for Ecotourism Operations. Those Practice Criteria for Ecotourism Operations are: The Ecotourism Operation is in keeping with the natural and cultural values of national park. The natural and cultural values of the site are inventoried, and its distinctive features are highlighted. Any device limitations or stressors are established, and sensitive and vulnerable areas are avoided in development and activities. The Ecotourism Operation is designed to fit within the character of the national park. The design and layout of Ecotourism Operation complement the surrounding landscape and natural features. By considering factors such as aspect and orientation, the design and layout optimize the 
sustainability of ecotourism facility and visitor comfort. The ecosystem is made up of endangered native plants. The Ecotourism Operation leaves the smallest possible footprint on the site. The design and operation of Ecotourism Operation have minimal impacts on the Site. The Ecotourism Operation encourages water and energy conservation, and visitor activity is driven by a "leave no trace" ethic. Waste and emissions are kept to a minimum. The Ecotourism Operation contributes to protecting and positively enhancing the national park.

The Ecotourism Operation, which works in collaboration with park management and local organizations to, for example, rehabilitate disturbed areas of the national park and inform staff and visitors about fundamental park values, contributes to the long-term sustainability of national park. Traditional owners and local communities are engaged, involved, and benefited by the ecotourism process. The significance of national park to cultural and economic interests of local communities is established, and long-term relationships are sought. The interpretation and experience of indigenous cultural resources are influenced by traditional owners. Visitors are encouraged to value the national park and want to preserve and maintain it through the ecotourism operation. The natural and cultural values of the site are correctly interpreted, and visitor activities and interactions contribute to their preservation and restoration (Queensland State, 2015). Flora and fauna, environment, water bodies (ocean, sea, rivers, lakes, hot springs, etc.), scenery, landscape, and other natural eco-attractions are well-known.

The status of biodiversity in the Entoto park was assessed as possible opportunities for the creation of ecotourism in the Entoto natural park in this study. In conclusion, the success of ecotourism is dependent on the nature of the natural and human environment. If properly planned and operated, ecotourism has the potential to reduce environmental impacts while also contributing significantly to the following areas: (i) ecotourism allows for the existence of several privately owned nature reserves in the tropics. These reserves depend on ecotourism more than any other form of income, and some are entirely reliant on it. (ii) the position of Ecotourism as a driving force behind the development of these parks shows a clear connection between biodiversity conservation and ecotourism. (iii) The social, ecological, and economic problems surrounding privately owned nature reserves are emerging, but they are largely unexplored. We know very little about their impacts, aside from simple descriptive knowledge about scale, habitat type, and job development. (iv) As demonstrated by the reserves in this report, it is possible for a reserve to operate solely on ecotourism revenues. "Traditional" and "formal" information structures must be connected to achieve ecosystem protection and sustainable use.

\section{REFERENCES}

African Union Commission-Economic Commission for Africa-African Development Bank (AUC-ECA-AfDB). 2010. Land Policy in Africa:
Eastern Africa Regional Assessment. ECA, PCMS, Addis Ababa, Ethiopia.

Amogne A. 2014. Ecotourism as a viable strategy for livelihood diversification and Sustainable Natural resource management in Ethiopia (from eco-development paradigm point of view). J Environ Sci Water Resour 3 (2): 40-52.

Arvaniditis PA. 2008. Economic aspects of urban green spaces: Survey of perceptions and attitudes. J Environ Technol Manag 11 (1): 144-165. DOI: 10.1504/IJETM.2009.027192.

Barber A. 2008. Start with the park: Creating Sustainable urban Green spaces in areas of housing growth and renewal. http://lifestyle.iloveindia.com/lounge/benefits-of- ecotourism8866.html\#sthash.zjToqdzF.dpuf

Beedasy J, Whyatt D. 1999. Diverting the tourists: a spatial Decisionsupport system for tourism planning on a developing Island. Elsevier, Int J Appl Earth Observ Geoinformation 1 (3-4): 163-174. DOI: 10.1016/S0303-2434(99)85009-0

Bunruamkaewa K, Murayama Y. 2011. Site suitability evaluation for ecotourism using GIS \& AHP: A case study of Surat, Thani Province, Thailand. Procedia Soc Behav Sci 21: 269-275. DOI: 10.1016/j.sbspro.2011.07.024

Carter S. 1995. Tourists and Travelers' social construction of Africa and Asia as risky places. Cater E. 1993. Ecotourism in the Third World: Problems for sustainable tourism development. Tourism Manag 14 (2): 85-90. DOI: 10.1016/0261-5177(93)90040-R

Congalton RG. 1991. A review of Assessing the Accuracy of Classification of Remotely sensed Data. University of California Berkeley, Berkeley, USA.

Ethiopian Biodiversity Institute (EBI). 2014. Ethiopia's Fifth National Report to the Convention on Biological Diversity (CBD). Unpublished technical report, EBI, Addis Ababa, Ethiopia.

Ethiopian Wildlife and natural History Society (EWNHS). 2015. Important Bird Areas in Ethiopia and associated islands-Ethiopia. Addis Ababa, Ethiopia.

Faust NL. 1989. Image Enhancement. Volume 20, Supplement 5 of Encyclopedia of Computer Science and Technology. Williams. Marcel Dekker, Inc., New York.

Fedorov E. 1980. Man and Nature. The Ecological Crisis and Social Progress. Progress Publishers, Moscow, USSR.

Gebrehiwot K, Hundera K. 2014. Species composition, Plant Community structure and Natural regeneration status of Belete Moist Evergreen Montane Forest, Oromia Regional state, Southwestern Ethiopia. Momona Ethiopian J Sci 6 (1): 97-101.

Haileselassie G, Getaneh A. 1989. The Addis Ababa-Nazaret Volcanics: A Miocene-Pleistocene volcanic succession in the Ethiopian Rift. SINET Ethiopian J Sci 12 (1): 1-24.

Hancock G. 1995. The Beauty of Addis Ababa. Camerapix Publishers International. Nairobi, Kenya.

Henze PB. 2007. Ecotourism in Ethiopia. http://www.irrob.org/ecotourism in_ethiopia.html on 21.11.2015.

Holloway JC. 1991. The Business of Tourism, $3^{\text {rd }}$ ed. Clays Ltd, England.

Jennifer B. 2013. Community ecotourism destinations open in Ethiopia's central and southern. http://www.counterpart.org/ accessed on 14.09.2015

Kazmierczak AE, James P. 2008. Urban Green Spaces: Natural and Usable. Leibniz (IOER), Dresden, Germany.

Kuchelmeister G, Braatz S. 2000. Trees for the urban millennium: urban forestry update. Unasylva 51: 50-55.

Langholz J. 1995. Ecotourism Impact on Independently Owned Nature Reserves in Latin America and Sub-Saharan Africa. Yale School For Environ Stud Bull Ser No. 99, New Haven, USA.

Logan G. 2012. Ethiopia Poised to Become Next Hot African Ecotravel Destination. http://ethiopia.usembassy.gov/pr3808.html accessed on 19.11.2015.

Mack MC, D'Antonio CM. 2007. Impacts of biological invasions on disturbance regime https://www.cbd.int/doc/world/et/et-nr-05-en.pdf accessed on 11.9.2015.

Malede B, Girma G. 2015. Review on problems, prospects and economic contribution of Wildlife Management and Ecotourism in Ethiopia. J Vet Sci Technol 6 (257): 2157-7579.

Mann S, Hawkins DE. 2006. The World Bank's role in Tourism Development. Ann Tourism Res 34 (2): 348-363. DOI: 10.1016/j.annals.2006.10.004

McIntyre N, Williams DR, McHugh KE. 2006. Multiple dwelling and tourism: negotiating place, home and identity. CABI, Wallingford, UK. DOI 10.1079/9780845931202.0000 
Mesfin T. 2009. Spatial Metrics and Landsat Data for Urban Landuse Change Detection in Addis Ababa, Ethiopia. Castellon, Spain.

National Meteorological Agency of Ethiopia (NMAE). 2014. Reports on Temperature and Rainfall characteristics of Ethiopia.

Okello MM, Wishitemi EL. 2003. Application of the protected landscape model in Southern Kenya. Parks 13 (2): 12-50.

Queensland State. 2015. Best Practice Ecotourism Development Guidelines. Queensland, Brisbane, Australia.

Rudolf PS, Ramakrishnan de G, Berg A van de, Kulenthran T, Muller S, Pitt D, Wascher D, Wijesuriya G. 2003. Cultural and amenity services. Ecosyst Hum Well-being: Curr State Trends 7: 457-462.

Shackleton CM. 2000. Biological conservation comparison of plant diversity in protected and communal lands in the Bushbuckridge Lowveld savanna, South Africa. Biol Conserv 94 (3): 273-285. DOI 10.1016/S0006-3207(00)00001-X.

Strasdas W. 2002. Ecotourism Training Manual for Protected Area Managers. German Foundation for International Development (DSE) Center For Food, Rural Development and the Environment. Feldafing and Zschortatu, Germany.

Teressa D. 2015. Development of community-based ecotourism in Wenchi Crater Lake, Ethiopia: Challenges and prospects. J Hospitality Tourism 6 (4): 39-46. DOI: 10.5897/JHMT2014.0133
Tesfaye T. 2009. Is Eucalyptus ecologically hazardous tree species? EeJIRF 1: 128-134.

Theodros A. 2004. Sustainable tourism development and ecotourism. Walia 24 (3): 34-41.

Tisdell C, Wilson C. 2005. Perceived Impacts of Ecotourism on Environmental Learning and Conservation: Turtle Watching as a Case Study. In: Environment, Development and Sustainability: A Multidisciplinary Approach to the Theory and Practice of Sustainable Development, Springer, Nederland. vol. 7 (3): 291-302. DOI: 10.1007/s10668-004-7619-6.

United Nations World Tourism Organization (UNWTO) (2016), 2015 ed. UNWTO Tourism Highlight, Madrid, Spain.

Wearing S, Neil J. 1999. Ecotourism: Impacts, Potentials, and Possibilities. $1^{\text {st }}$ ed. Reed Educational and Professional Publishing Ltd, Great Britain.

Whittaker RH. 1960. Vegetation of the Siskiyou Mountains, Oregon and California. Ecol Monogr 30: 279-338.

William D. 2009. Entoto Natural Park-an environmental success story in the making. Selamta 26 (3): 50-52.

World Commission on Environment and Development (WCED). 1987. Our Common Future. Oxford University Press, New York. 